\title{
Screening of mycota associated with Aijung rice seed and their effects on seed germination and seedling vigour
}

\author{
Islam $\mathrm{NF}^{1^{*}}$ and Borthakur SK ${ }^{2}$ \\ ${ }^{1}$ Department of Botany, N.N. Saikia College, Titabar-785630, Jorhat, Assam, India \\ ${ }^{2}$ Department of Botany, Gauhati University, Guwahati, Assam, India
}

Islam NF, Borthakur SK - Screening of mycota associated with Aijung rice seed and their effects on seed germination and seedling vigour. Plant Pathology \& Quarantine 2(1), 75-85, doi $10.5943 / \mathrm{ppq} / 2 / 1 / 11$

Experiments were conducted to evaluate the effect of some dominant seed borne fungi of Aijung rice variety on seed germination and seedling vigour. Twenty dominant fungi were found associated with Aijung rice seeds. Analysis of seed borne fungi by blotter method and agar plate method showed that species of Aspergillus, Fusarium, Alternaria and Curvularia are the dominant genera. Seed germination and seedling vigour tests were conducted using seed inoculation, soil inoculation and seed submergence method. Maximum reduction in seed germination and seedling vigour was caused by species of Fusarium in seed inoculation method, by species of Rhizopus and Fusarium in soil inoculation method and by species of Aspergillus in seed submergence method. In another experiment healthy rice seeds were soaked in 25, 50, 75 and 100\% concentration of 7-, 14- and 21day-old culture filtrates of the isolated seed borne fungi. Maximum reduction in seed germination was recorded from 21-day-old culture filtrates. The inhibitory effect on seed germination was found to decrease with increase in dilution of the filtrates.

Key words - germination - incubation - seed inoculation - vigour index

\section{Article Information}

Received 2 May 2012

Accepted 29 May 2012

Published online 20 June 2012

*Corresponding author: Islam NF-email-nazimforidislam@yahoo.co.in

\section{Introduction}

Every seed is a potential harbour of a wide variety of microfungi containing both pathogenic and saprophytic microorganisms, both externally and internally (Utobo et al. 2011). These microfungi may reduce seed quality and impair seed germination resulting in the production of abnormal seedlings (Paul 1989, Vijayan \& Rehill 1990, Bateman \& Kwasna 1999, Khanzada et al. 2002). In case of severe infection the seed completely deteriorates and the grain may become unsuitable even for animal consumption due to production of mycotoxic substances by seed fungi.
Rice (Oryza sativa L.) is the most widely grown cereal crop in the world. Rice seeds are infected by large number of fungi that are reported to perpetuate from one season to another through infected seeds (Zope \& Thrimurty 2004). Moreover, high rainfall and humidity during Kharif season expose paddy seeds to fungal invasions. Several fungal pathogens have been isolated from rice grains and have been reported to be responsible for a number of diseases from the nursery to the field (Ibiam et al. 2006). These fungi have been shown to play a role in reducing germination and seedling vigour (Subramanyam 1991, Gupta \& Chouhan 1970, Dharamvir 1973). 


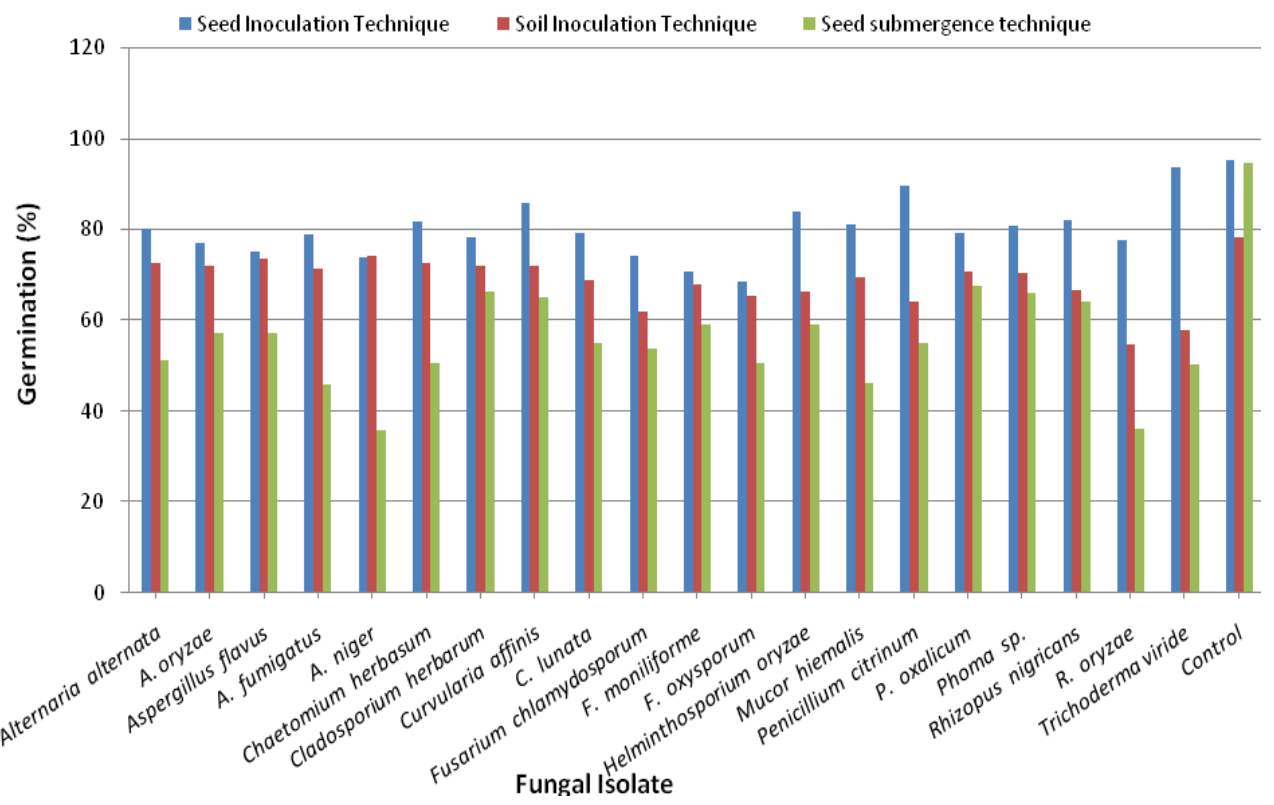

Fig. 1 - Effect of seed borne fungi (seed inoculation, soil inoculation and seed submergence method) on rice seed germination

The present investigation deals with isolation of fungi associated with Aijung variety of rice seed and their effects on seed germination and seedling vigour.

\section{Materials and methods}

\section{Site description}

The study area is situated in south of the river Brahmaputra, Assam, North-East India $\left(26^{\circ} 12^{\prime} \mathrm{N}, 91^{\circ} 50^{\prime} \mathrm{E}\right)$ with an average altitude of $54 \mathrm{~m}$ (a.s.l). Healthy rice seeds of Aijung variety were collected from a local farmer in the study area. The variety is most widely cultivated in this region due to its high yield and adaptability to the prevailing climatic condition. The climate of the area is monsoonal, characterised by a long rainy season (MaySeptember) and dry and cold winter (November-February). The average annual rainfall was about $1782 \mathrm{~mm}$ during the study period, with highest rainfall $(315.5 \mathrm{~mm})$ in September. The hottest month of the year was August with a mean maximum temperature of $33.0^{\circ} \mathrm{C}$ and the coldest month was January with a mean minimum temperature of $9.9^{\circ} \mathrm{C}$. Maximum relative humidity recorded during the study period was $85 \%$ in the month of July.

\section{Microbial assay of rice seeds}

Microbiological assay of the mycota associated with rice seeds were carried out using standard blotter method (ISTA 1976) and nutrient agar plate method (Muskett 1948).

\section{Standard Blotter Method}

Unsterilized as well as sterilised rice seeds were placed on three sets of moist blotter paper at the rate of 10 seeds/ Petri plate. The experiment was laid with 20 replications each for sterilised and unsterilised seeds. For analysis of internal seed borne fungi seed were surface sterilised with $2.5 \%$ sodium hypochlorite solution for one minutes followed by 3-4 washings with sterile distilled water before plating, while unsterilised seeds were plated without treatment. The plated seeds were incubated at $25 \pm 2{ }^{\circ} \mathrm{C}$ in an incubator for 7 days. Sterile distilled water was sprayed aseptically on the Petri plates every third day in order to keep the blotters sufficiently moist. After incubation fungi were isolated by pure culture method. Further slides were prepared and examined under a compound microscope for identification of the isolated fungi.

\section{Agar Plate Method}

The other set of experiment was carried out on potato dextrose agar (PDA) medium. Similar to blotter method, 20 replicates were taken each for unsterilised and sterilised seeds at a rate of 10 seeds/Petri 


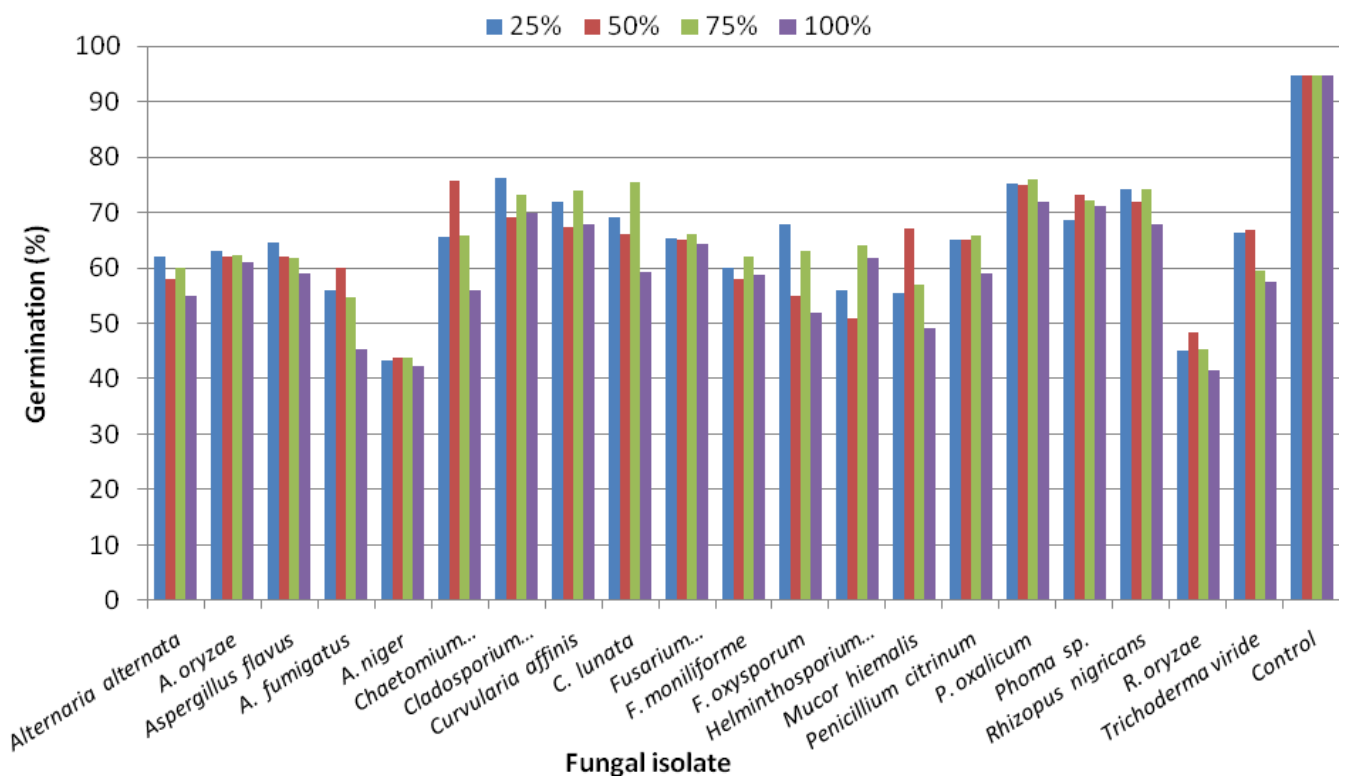

Fig. 2 - Effect of 7-day-old culture filtrate at different concentrations on rice seed germination

plate. The seeds were placed on sterilised glass Petri plates containing $20 \mathrm{~mL}$ potato dextrose agar medium. The plates were incubated at 25 $\pm 2^{\circ} \mathrm{C}$ for 7 days. Through constant observation during the incubation period, growth characteristics of fungal colonies were recorded. At the end of the incubation period, pure cultures of fungi growing out of seeds were prepared on suitable agar slants for further examination.

\section{Effect of seed borne fungi on germination and seedling vigour}

The effect of seed borne on germination and seedling vigour was analysed as per method of Singh \& Swami (2004).

\section{Seed inoculation method}

Rice seeds were surface sterilised with $2.5 \%$ sodium hypochlorite solution for one minute followed by several washings with sterile distilled water before plating. Sterilised seeds were inoculated by rolling over 10-daysold sporulating culture of each fungus grown on PDA. The inoculated seeds were air dried for $72 \mathrm{~h}$ at room temperature. The inoculated seeds were plated over three layers of moist blotter paper. Three replicate of 10 seeds each were taken for each treatment. Equal number of healthy sterilised seeds without inoculation plated over moist blotter paper served as control. Treated and control plates were incubated at $25 \pm 2{ }^{\circ} \mathrm{C}$ for 14 days. After incubation, observation on percent germination, radical and plumule length and seedling vigour were recorded.

Germination percent was recorded as:

Germination $(\%)=$ Number of seeds germinated/ Total number of seeds used $\times 100$

Seedling vigour was determined following the formula of Baki \& Anderson (1972):

Vigour index $=($ Mean of root length + Mean of shoot length) $\times$ Percentage of seed germination

\section{Soil inoculation method}

The isolated fungi were grown separately on autoclaved rice medium (10:5 rice/water) in $100 \mathrm{~mL}$ conical flasks. The flasks were incubated at $25 \pm 2^{\circ} \mathrm{C}$ for 10 days. Sterilised earthen pots $(30 \mathrm{~cm})$ were filled with pre-sterilised soil. For inoculation, the upper 5 $\mathrm{cm}$ layer of soil was thoroughly mixed with rice medium for supporting the fungal growth. The pots were covered with polythene bags and left for $24 \mathrm{~h}$ in a green house. After $24 \mathrm{~h}$ healthy sterilised rice seeds were sown in each pot. Three replicates of 10 seeds each were taken for each treatment. Equal number of healthy sterilised seeds sown in uninoculated pot served as control. After 14 days, observation on percent germination and seedling vigour were recorded. 


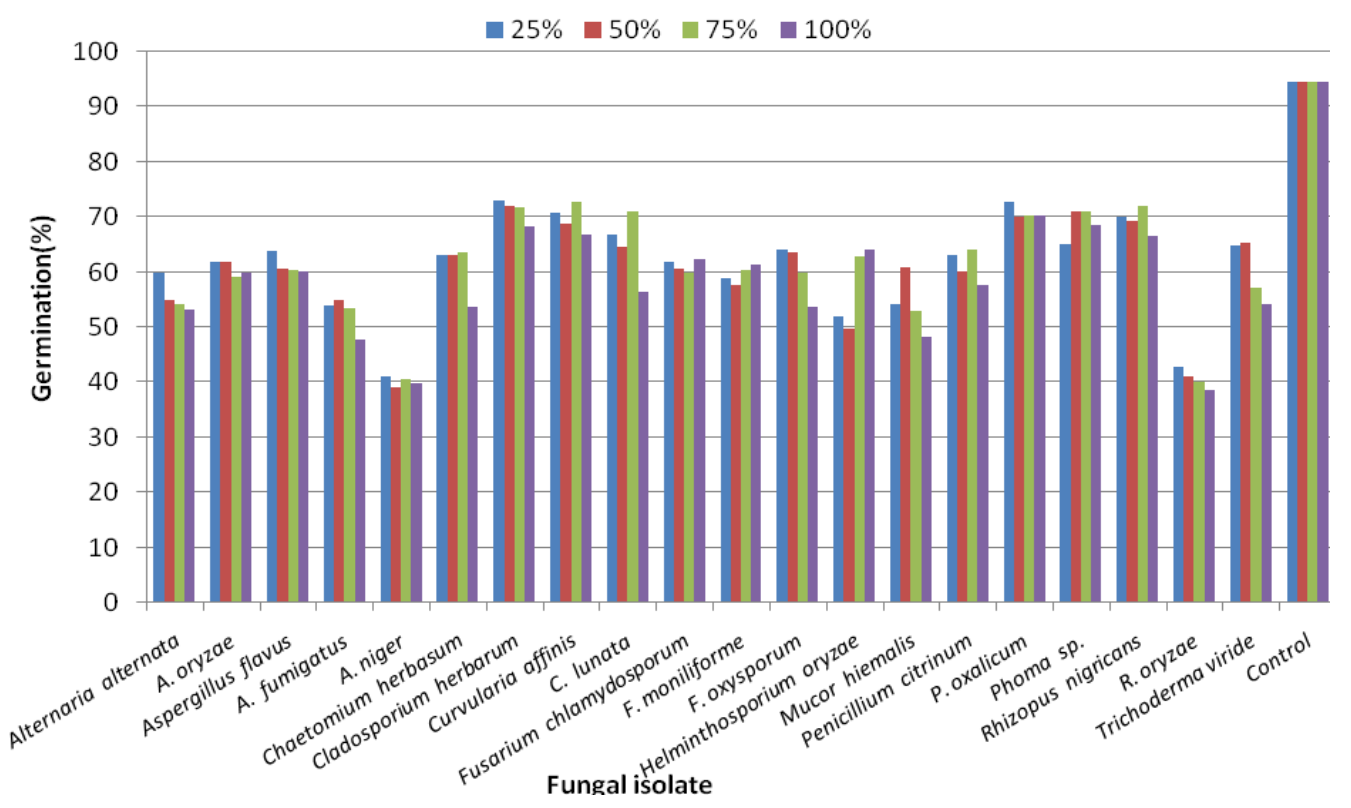

Fig. 3 - Effect of 14-day-old culture filtrate at different concentrations on rice seed germination

Seed submergence method

The isolated fungi were grown separately in Richard's broth medium and incubated for 21 days at temperature of $25 \pm$ $2^{\circ} \mathrm{C}$. Culture filtrates were obtained by filtering the contents through Whatman filter paper no. 44. Healthy surface sterilised rice seeds were separately soaked in these culture filtrates for $24 \mathrm{~h}$ and allowed to germinate in sterilised plates containing three layers of moist sterile blotter paper. Seeds soaked in uninoculated sterilised medium and sterile water served as control. Petri plates were incubated at $25 \pm 2{ }^{\circ} \mathrm{C}$ for 14 days. After incubation, percent seed germination and seedling vigour were recorded.

\section{Effect of different concentration of culture filtrates on rice seed germination}

Surface sterilised seeds were soaked for $24 \mathrm{~h}$ in different concentration $(25,50,75$, and 100) of 7-, 14- and 21-day-old culture filtrate of each fungus. Dilution was made with sterile distilled water. Three replicates of 10 seeds were taken for each concentration, days and fungus. Equal number of seeds soaked in sterile distilled water served as control. The soaked seeds were plated on three layers of moist blotter paper and incubated at $25 \pm 2{ }^{\circ} \mathrm{C}$ for 14 days. After incubation, percent germination was recorded.

\section{Results}

\section{Microbial assay of seed mycota}

Twenty fungal species belonging to 12 genera were isolated from Aijung rice seeds (Table 1). More fungi were recorded in agar plate method than in the blotter method. In blotter method the highest percent incidence was recorded by Alternaria alternata (4.7\%), followed by Aspergillus fumigatus (4.5\%) and A. niger $(3.7 \%)$ in case of surface sterilised seeds. The lowest incidence was detected for Penicillium citrinum (1.2\%). In case of unsterilised seeds, the highest percent incidence was noted with Curvularia affinis (5.2\%) followed by Penicillium oxalicum (4.9\%) and $P$. citrinum (4.8\%) and the lowest by Fusarium chlamydosporium and Rhizopus nigricans (2.6\% each). Similarly, in agar plate method, the highest percentage of occurrence was recorded with Alternaria alternata (5.5\%), followed by Aspergillus fumigatus (4.7\%) and A. niger $(4.5 \%)$ in case of surface sterilised seeds. The lowest incidence was detected in Cladosporium herbarum, Fusarium moniliforme and Rhizopus nigricans $(2.1 \%$ each). In case of unsterilised seeds the highest percent of incidence was shown by Penicillium oxalicum (5.2\%), followed by Aspergillus fumigatus and Fusarium moniliforme (5.1\% each) and the lowest by Fusarium chlamydosporium (2.8\%). 
Table 1 Incidence of fungi associated with rice seed evaluated by standard blotter method and agar plate method

\begin{tabular}{|c|c|c|c|c|}
\hline \multirow[t]{2}{*}{ Fungi } & \multicolumn{4}{|c|}{$\%$ incidence } \\
\hline & \multicolumn{2}{|c|}{ Standard blotter method } & \multicolumn{2}{|c|}{ Agar plate method } \\
\hline & SS & US & SS & US \\
\hline Alternaria alternata (Fr.) Keissl. & 4.7 & 4.0 & 5.5 & 4.3 \\
\hline A. oryzae Hara & 2.5 & 3.5 & 3.2 & 4.2 \\
\hline Aspergillus flavus Link. & 2.1 & 3.5 & 3.5 & 4.3 \\
\hline A. fumigatus Fresen. & 4.5 & 4.2 & 4.7 & 5.1 \\
\hline A. niger van Tiegh. & 3.7 & 4.2 & 4.5 & 4.8 \\
\hline Chaetomium sp. & 2.2 & 4.0 & 3.5 & 4.1 \\
\hline Cladosporium herbarum (Pers.)Link & 2.0 & 4.2 & 2.1 & 4.6 \\
\hline Curvularia affinis Boedijn & 3.0 & 5.2 & 0.0 & 6.0 \\
\hline C. lunata (Wakker) Boedijn & 2.4 & 3.9 & 3.3 & 4.4 \\
\hline Fusarium chlamydosporum Wollenw. \& Reinking & 0.0 & 2.6 & 2.2 & 2.8 \\
\hline F. moniliformae J. Sheld. & 1.7 & 4.2 & 2.1 & 5.1 \\
\hline F. oxysporum Schltdl. & 2.2 & 3.9 & 4.2 & 4.9 \\
\hline Helminthosporium oryzae Breda de Haan & 2.0 & 4.2 & 4.2 & 4.4 \\
\hline Mucor hiemalis Wehmer & 2.4 & 3.9 & 2.5 & 4.0 \\
\hline Penicillium citrinum Thom & 1.2 & 4.8 & 2.3 & 5.0 \\
\hline P. oxalicum Currie \& Thom & 2.7 & 4.9 & 0.0 & 5.2 \\
\hline Phoma sp. & 1.7 & 3.9 & 0.0 & 4.0 \\
\hline Rhizopus nigricans Ehrenb. & 0.0 & 2.6 & 2.1 & 3.2 \\
\hline$R$. oryzae Went \& Prins. & 2.0 & 3.9 & 2.3 & 4.0 \\
\hline Trichoderma sp. & 2.5 & 3.1 & 2.5 & 3.5 \\
\hline Seeds without mycota & 54.5 & 21.3 & 45.3 & 12.1 \\
\hline No. of genera & 12 & 12 & 11 & 12 \\
\hline No. of species & 18 & 20 & 17 & 20 \\
\hline
\end{tabular}

US- unsterilized seeds; SS-sterilized seeds;

Some fungi viz., Fusarium chlamydosporium and Rhizopus nigricans were absent in surface sterilised seeds but present in non-surface sterilised seeds in blotter method. In agar plate method Curvularia affinis, Penicillium oxalicum and Phoma sp. were absent from surface sterilised seeds.

Effect of seed borne fungi on seed germination and seedling vigour (seed inoculation method)

Results on the effect of seed borne fungi on germination and seedling vigour obtained by seed inoculation method are presented in the Table 2. The percent germination of seeds was markedly suppressed by all fungi. Maximum percent inhibition in germination over control was observed in the seeds inoculated with Fusarium oxysporum (28\%) followed by Fusarium moniliforme (25.8\%), Aspergillus niger (22.4\%) and Fusarium chlamydosporum (22.3\%). The lowest inhibition of germination was shown by seeds treated with inoculum of Trichoderma viride (1.8\%) and Penicillium citrinum (6.1\%). Germination percentages of treated seeds were statistically significant at .05 level. Maximum decrease in shoot length $(7.3 \mathrm{~cm})$ was observed in seeds inoculated with Fusarium moniliforme and root length $(3.4 \mathrm{~cm})$ in Chaetomium herbarum inoculated seeds. The mean differences were statistically significant. The highest vigour index (1394.8) of seedling was obtained from seeds inoculated with Phoma sp. and the lowest (817.6) was recorded in Fusarium moniliforme inoculated seeds.

Effect of seed borne fungi on seed germination and seedling vigour (soil inoculation method)

Table 3 reveals the effect of seed borne fungi on germination and seedling vigour by soil inoculation method. Highest percent inhibition in germination $(30.1 \%)$ over control was recorded in the seeds sown in Rhizopus oryzae inoculated soils followed by 


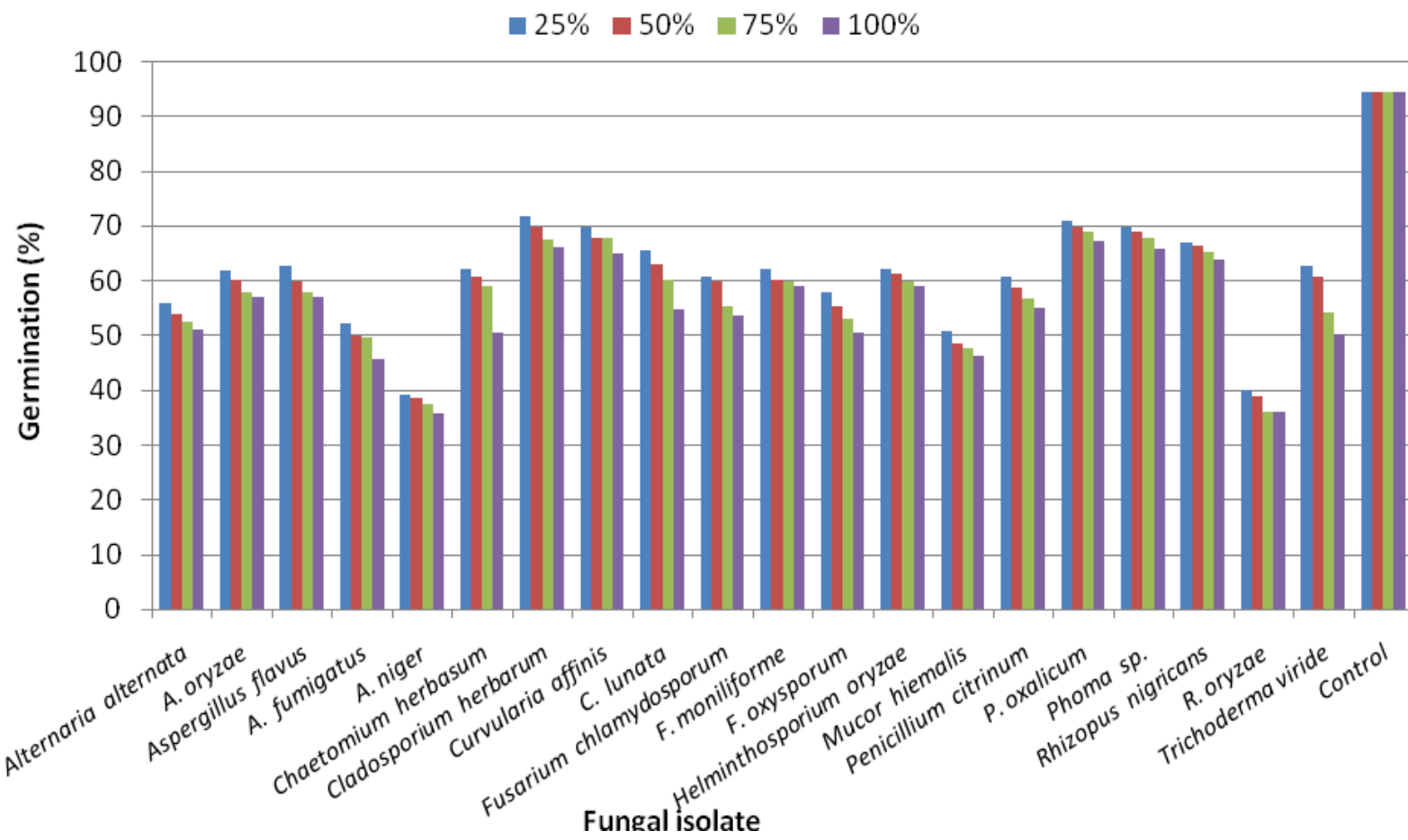

Fig. 4 - Effect of 21-day-old culture filtrate at different concentrations on rice seed germination

Trichoderma viride (26.2\%), Fusarium chlamydosporium $(20.6 \%)$ and Penicillium citrinum (18.2\%). Lowest inhibition was observed in soil treated with inoculum of Aspergillus niger (5.3\%). Germination percenttages were found to be statistically significant at .05 level. Maximum reduction in shoot length $(6 \mathrm{~cm})$ was observed in Rhizopus nigricans inoculated soils and root length $(3.3$ $\mathrm{cm})$ in Chaetomium herbasum inoculated soils. The highest vigour index (1038.2) was in seedlings obtained from Aspergillus flavus inoculated soils and the lowest (603.5) was recorded from Fusarium chlamydosporum inoculated soils.

Effect of seed borne fungi on seed germination and seedling vigour (seed submergence method)

Rice seeds soaked in culture filtrate of individual fungi showed reduction in percent germination and seedling vigour over control (Table 4). Maximum inhibition in germination $(62 \%)$ over control and reduction in seedling vigour (322.7) was recorded from seeds soaked in culture filtrate of Aspergillus niger (62.05\%) followed by filtrate of Rhizopus oryzae (61.7\%), Aspergillus fumigatus (51.5\%) and Trichoderma viride (46.9\%). Minimum inhibition in germination was recorded with culture filtrate of Penicillium oxalicum (28.69\%). Maximum reduction in shoot length was recorded in culture filtrate of Penicillium oxalicum $(5.5 \mathrm{~cm})$ and root length in culture filtrate of Fusarium moniliforme $(3 \mathrm{~cm})$. The highest vigour index (861.9) of seedlings was observed in culture filtrate of Curvularia affinis and the lowest (322.7) was recorded in filtrate of Aspergillus niger.

Fig. 1 shows a comparison between seed germination as affected by seed borne fungi recorded by the three methods. Germination percentage ranged from $36 \%$ to $94 \%$. Maximum inhibition in seed germination over control were due to the effect of culture filtrates of the isolated fungi compared to inhibition shown by fungi inoculated through seed and soil. Maximum inhibition was shown by Aspergillus niger (62\%) as estimated by seed submergence method and minimum by Trichoderma viride (2\%) estimated through seed inoculation method.

\section{Effect of culture filtrates at different concentration on rice seed germination}

Figs 2, 3 and 4 reveals efficacy of 7, 14, and 21 day old culture filtrates at four different concentrations on seed germination. Data 
Table 2 Effect of seed borne fungi on seed germination and seedling vigour (seed inoculation method)

\begin{tabular}{|c|c|c|c|c|c|}
\hline Fungi & $\begin{array}{c}\% \\
\text { Germination }\end{array}$ & $\begin{array}{c}\% \text { inhibition of } \\
\text { germination over } \\
\text { control }\end{array}$ & $\begin{array}{l}\text { Shoot length } \\
\text { (cm) }\end{array}$ & $\begin{array}{l}\text { Root length } \\
\text { (cm) }\end{array}$ & $\begin{array}{l}\text { Vigour } \\
\text { index }\end{array}$ \\
\hline Alternaria alternata & $80.10 \pm 0.66$ & 15.97 & $9.15 \pm 1.27$ & $4.58 \pm 0.93$ & 1099.73 \\
\hline A. oryzae & $77.03 \pm 3.42$ & 19.19 & $8.78 \pm 0.75$ & $4.93 \pm 0.11$ & 1056.08 \\
\hline Aspergillus flavus & $75.00 \pm 2.08$ & 21.32 & $9.95 \pm 1.07$ & $5.53 \pm 0.32$ & 1161.00 \\
\hline A. fumigatus & $79.00 \pm 1.77$ & 17.12 & $8.84 \pm 0.58$ & $3.83 \pm 0.63$ & 1000.93 \\
\hline A. niger & $73.93 \pm 2.46$ & 22.44 & $7.59 \pm 0.20$ & $4.30 \pm 0.30$ & 879.02 \\
\hline Chaetomium herbasum & $81.83 \pm 5.92$ & 14.16 & $10.73 \pm 1.19$ & $3.36 \pm 0.27$ & 1152.98 \\
\hline Cladosporium herbarum & $78.23 \pm 6.41$ & 17.93 & $8.63 \pm 0.37$ & $4.73 \pm 0.37$ & 1045.15 \\
\hline Curvularia affinis & $85.80 \pm 0.75$ & 9.99 & $8.56 \pm 0.75$ & $6.56 \pm 0.24$ & 1297.29 \\
\hline C. lunata & $79.20 \pm 3.08$ & 16.92 & $10.86 \pm 0.24$ & $4.33 \pm 0.88$ & 1203.04 \\
\hline Fusarium chlamydosporum & $74.00 \pm 1.92$ & 22.37 & $13.06 \pm 1.27$ & $4.03 \pm 0.38$ & 1264.66 \\
\hline F. moniliforme & $70.73 \pm 2.94$ & 25.80 & $7.33 \pm 0.93$ & $4.23 \pm 0.13$ & 817.63 \\
\hline F. oxysporum & $68.63 \pm 1.04$ & 28.00 & $8.99 \pm 0.61$ & $3.56 \pm 0.28$ & 861.30 \\
\hline Helminthosporium oryzae & $84.00 \pm 2.28$ & 11.88 & $9.58 \pm 1.32$ & $4.90 \pm 0.58$ & 1216.32 \\
\hline Mucor hiemalis & $80.99 \pm 3.60$ & 15.04 & $8.92 \pm 0.60$ & $3.93 \pm 0.57$ & 1040.72 \\
\hline Penicillium citrinum & $89.50 \pm 1.15$ & 6.11 & $8.45 \pm 0.27$ & $4.30 \pm 0.41$ & 1141.12 \\
\hline P. oxalicum & $79.30 \pm 7.40$ & 16.81 & $9.21 \pm 0.71$ & $5.33 \pm 0.33$ & 1153.02 \\
\hline Phoma sp. & $80.86 \pm 3.55$ & 15.17 & $10.29 \pm 1.29$ & $6.96 \pm 0.57$ & 1394.83 \\
\hline Rhizopus nigricans & $82.00 \pm 2.51$ & 13.98 & $9.62 \pm 0.31$ & $6.66 \pm 0.61$ & 1334.96 \\
\hline R. oryzae & $77.60 \pm 6.20$ & 18.59 & $9.22 \pm 0.37$ & $5.53 \pm 0.63$ & 1144.60 \\
\hline Trichoderma viride & $93.57 \pm 1.96$ & 1.84 & $9.66 \pm 0.71$ & $4.33 \pm 0.66$ & 1309.04 \\
\hline Control & $95.33 \pm 0.89$ & & $13.89 \pm 0.37$ & $6.95 \pm 0.71$ & \\
\hline SEm & 1.00 & & 0.22 & 0.15 & \\
\hline $\operatorname{LSD}(.05)$ & .004 & & .016 & .007 & \\
\hline
\end{tabular}

Mean \pm SEm, $\mathrm{n}=3$

revealed that there was marked inhibition in the rate of seed germination from 7-day to 21-dayold filtrate. Filtrates of $100 \%$ concentration were found to be more effective in inhibiting seed germination than that of other concentrations. Seven-day old filtrate produced 41 to $76 \%$ seed germination, whereas 14 and 21 day old filtrates produced 39 to $73 \%$ and 36 to $71 \%$ seed germination as compared to control $(95 \%)$. The results indicate that rice seeds were sensitive to filtrates of all the isolated fungi. The inhibitory effect of the filtrates on seed germination decreased with increase in dilution but in no case was seed germination observed to be more than that of the control.

\section{Discussion}

The study revealed a wide range of fungi associated with rice seeds. Twenty different fungi were isolated from the rice seeds. Some of these fungi may be associated with the whole seed, some with the tissues of seed coat, embryo and cotyledon (Popoola \& Akueshi 1986).Percent incidence of seed mycota was higher in agar plates as compared to blotter method. This may be attributed to the ability of agar plates to support growth of various fungal species, and due to the higher osmotic potential of PDA medium that showed its substrate efficiency for promoting the colonising rates of both external and internal seed fungal types. The results reveal both qualitative and quantitative variations of the prevalence of the fungal population in terms of percent incidence in two methods of isolation. In the present investigation some of the species or genera are found more frequently, some are noticed occasionally and some of were entirely absent. Seed treatment with sodium hypochlorite is observed to minimise or eliminate some of the externally seed borne (Jaffe 1968). Fungi isolated from unsterilised rice seed are externally seed borne and can probably be considered as either epiphytic or as mere chance contaminants (Suhag \& Suryanarayan 1975, Vishnuvat \& Shukla 1979, Ram et al. 1997, Prasad \& Choudhary 1978, Khare 1996). These externally associated fungi are also known to cause deterioration 
Table 3 Effect of seed borne fungi on seed germination and seedling vigour (soil inoculation method)

\begin{tabular}{|c|c|c|c|c|c|}
\hline Fungi & $\begin{array}{c}\% \\
\text { Germination }\end{array}$ & $\begin{array}{l}\text { \% inhibition of } \\
\text { germination } \\
\text { over control } \\
\end{array}$ & $\begin{array}{l}\text { Shoot length } \\
(\mathrm{cm})\end{array}$ & $\begin{array}{l}\text { Root length } \\
\quad(\mathrm{cm})\end{array}$ & $\begin{array}{l}\text { Vigour } \\
\text { index }\end{array}$ \\
\hline Alternaria alternata & $72.66 \pm 2.09$ & 7.04 & $7.77 \pm 0.54$ & $4.83 \pm 0.60$ & 915.51 \\
\hline A. oryzae & $71.96 \pm 2.58$ & 7.94 & $8.26 \pm 0.89$ & $4.43 \pm 0.29$ & 913.17 \\
\hline Aspergillus flavus & $73.53 \pm 2.58$ & 5.93 & $9.12 \pm 0.94$ & $5.00 \pm 0.36$ & 1038.24 \\
\hline A. fumigatus & $71.26 \pm 0.37$ & 8.88 & $7.14 \pm 0.19$ & $4.33 \pm 0.20$ & 817.35 \\
\hline A. niger & $74.00 \pm 2.67$ & 5.33 & $6.44 \pm 0.28$ & $3.76 \pm 0.14$ & 754.80 \\
\hline Chaetomium herbasum & $72.46 \pm 1.07$ & 7.30 & $9.23 \pm 0.84$ & $3.26 \pm 0.17$ & 905.02 \\
\hline Cladosporium herbarum & $71.96 \pm 1.51$ & 7.94 & $7.26 \pm 0.26$ & $3.71 \pm 0.22$ & 789.40 \\
\hline Curvularia affinis & $72.05 \pm 1.01$ & 7.82 & $7.81 \pm 0.68$ & $5.72 \pm 0.14$ & 974.83 \\
\hline C. lunata & $68.76 \pm 0.62$ & 12.03 & $9.18 \pm 0.76$ & $4.26 \pm 0.89$ & 924.13 \\
\hline Fusarium chlamydosporum & $62.03 \pm 1.73$ & 20.64 & $6.33 \pm 0.88$ & $3.40 \pm 0.17$ & 603.55 \\
\hline F. moniliforme & $67.83 \pm 1.08$ & 13.22 & $6.56 \pm 0.29$ & $3.68 \pm 0.11$ & 694.57 \\
\hline F. oxysporum & $65.33 \pm 0.88$ & 16.42 & $8.93 \pm 0.54$ & $3.65 \pm 0.28$ & 821.85 \\
\hline Helminthosporium oryzae & $66.40 \pm 0.80$ & 15.05 & $8.55 \pm 0.73$ & $4.32 \pm 0.61$ & 854.56 \\
\hline Mucor hiemalis & $69.30 \pm 0.98$ & 11.34 & $7.66 \pm 0.13$ & $4.55 \pm 0.17$ & 846.15 \\
\hline Penicillium citrinum & $63.93 \pm 3.08$ & 18.21 & $7.03 \pm 0.69$ & $3.79 \pm 0.20$ & 691.72 \\
\hline P. oxalicum & $70.83 \pm 0.42$ & 9.38 & $7.43 \pm 0.93$ & $4.80 \pm 0.46$ & 866.25 \\
\hline Phoma sp. & $70.33 \pm 3.08$ & 10.02 & $6.16 \pm 0.83$ & $6.19 \pm 0.44$ & 868.57 \\
\hline Rhizopus nigricans & $66.60 \pm 3.57$ & 14.80 & $6.00 \pm 0.55$ & $7.22 \pm 0.33$ & 880.45 \\
\hline R. oryzae & $54.63 \pm 2.68$ & 30.11 & $6.33 \pm 0.20$ & $5.64 \pm 0.35$ & 653.92 \\
\hline Trichoderma viride & $57.66 \pm 4.97$ & 26.23 & $8.18 \pm 0.29$ & $4.32 \pm 0.66$ & 720.75 \\
\hline Control & $78.17 \pm 0.88$ & & $9.57 \pm 0.23$ & $6.55 \pm 0.20$ & \\
\hline SEm & 0.78 & & 0.18 & 0.14 & \\
\hline $\operatorname{LSD}(.05)$ & .002 & & .003 & .001 & \\
\hline
\end{tabular}

Mean \pm SEm, $\mathrm{n}=3$

of seeds by reducing their viability or germinability (Jayaweera et al. 1988). Such a type of deterioration could be due to seed borne fungi which are not only associated externally but also harboured internally in tissues of seed coat, embryo, and cotyledon or through cracks or pits.

The effect of all the isolated fungi as estimated by seed inoculation, soil inoculation and seed submergence method showed significant reduction in the seed germination and seedling vigour. It is likely that fungi which reduced seed germination are pathogenic to host seedlings at the pre-emergence stage (Jayaweera et al. 1988). Fusarium inoculated seeds showed maximum inhibition of germination in both the seed inoculation and soil inoculation method. The role of Fusariumin inhibiting germination has been reported earlier by Utobo et al. (2011). Fusarium is known to invade the seed coat, endosperm and embryo resulting in failure in germination. Further, species of Fusarium are known to produce phytotoxins which probably interfere with germination (Ellis 1971, Neergard 1977, Suryanarayana 1978, Kanapathipillai \& Hashim 1982). Species of Aspergillus and Rhizopus were the next important inhibitor of germination encountered in the present study. In seed submergence method Aspergillus was found to be most potent inhibitor of germination followed by Fusarium. The adverse effect of Aspergillus on the germination of cereals has been reported in the recent years (Kanujia \& Singh 1975). Species of Aspergillus although regarded as surface contaminant were also responsible for production of aflatoxins and also been known to deteriorate rice grains (Imolehin 1987).

Among the isolated fungi Fusarium moniliforme, Rhizopus nigricans and Penicillium oxalicum caused marked reduction in shoot length, whereas Chaetomium herbasum and Fusarium moniliforme caused marked reduction in root length. Fusarium moniliforme, F. chlamydosporum and Aspergillus niger caused reduction in vigour index. 
Table 4 Effect of seed borne fungi on seed germination and seedling vigour (seed submergence method)

\begin{tabular}{|c|c|c|c|c|c|}
\hline Fungi & $\begin{array}{c}\% \\
\text { Germination }\end{array}$ & $\begin{array}{l}\text { \% inhibition of } \\
\text { germination } \\
\text { over control }\end{array}$ & $\begin{array}{l}\text { Shoot length } \\
\text { (cm) }\end{array}$ & $\begin{array}{l}\text { Root length } \\
\quad(\mathrm{cm})\end{array}$ & $\begin{array}{l}\text { Vigour } \\
\text { index }\end{array}$ \\
\hline Alternaria alternata & $51.23 \pm 0.53$ & 45.85 & $7.77 \pm 0.16$ & $5.49 \pm 0.28$ & 679.30 \\
\hline A. oryzae & $57.13 \pm 0.52$ & 39.61 & $6.55 \pm 0.29$ & $4.44 \pm 0.29$ & 627.85 \\
\hline Aspergillus flavus & $57.23 \pm 0.39$ & 39.50 & $6.86 \pm 0.44$ & $3.44 \pm 0.28$ & 589.46 \\
\hline A. fumigatus & $45.83 \pm 1.09$ & 51.55 & $6.40 \pm 0.17$ & $3.70 \pm 0.19$ & 462.88 \\
\hline A. niger & $35.90 \pm 1.05$ & 62.05 & $5.81 \pm 0.15$ & $3.18 \pm 0.15$ & 322.74 \\
\hline Chaetomium herbasum & $50.62 \pm 0.26$ & 46.49 & $6.84 \pm 0.10$ & $3.27 \pm 0.14$ & 511.76 \\
\hline Cladosporium herbarum & $66.30 \pm 1.16$ & 29.92 & $6.90 \pm 0.11$ & $3.33 \pm 0.19$ & 678.24 \\
\hline Curvularia affinis & $65.00 \pm 0.57$ & 31.29 & $7.75 \pm 0.14$ & $5.51 \pm 0.26$ & 861.90 \\
\hline C. lunata & $54.93 \pm 0.88$ & 41.94 & $6.79 \pm 0.15$ & $4.54 \pm 0.25$ & 622.35 \\
\hline Fusarium chlamydosporum & $53.63 \pm 1.31$ & 43.31 & $6.44 \pm 0.25$ & $3.50 \pm 0.21$ & 533.08 \\
\hline F. moniliforme & $59.00 \pm 0.57$ & 37.63 & $6.49 \pm 0.29$ & $3.00 \pm 0.14$ & 559.91 \\
\hline F. oxysporum & $50.66 \pm 1.20$ & 46.45 & $8.33 \pm 0.22$ & $3.36 \pm 0.20$ & 592.21 \\
\hline Helminthosporium oryzae & $58.96 \pm 0.98$ & 37.68 & $7.41 \pm 0.29$ & $3.65 \pm 0.24$ & 652.09 \\
\hline Mucor hiemalis & $46.20 \pm 1.77$ & 51.16 & $6.76 \pm 0.11$ & $4.13 \pm 0.14$ & 503.11 \\
\hline Penicillium citrinum & $55.13 \pm 1.12$ & 41.72 & $7.41 \pm 0.22$ & $3.48 \pm 0.27$ & 600.36 \\
\hline P. oxalicum & $67.46 \pm 0.86$ & 28.69 & $5.49 \pm 0.26$ & $4.54 \pm 0.26$ & 676.62 \\
\hline Phoma sp. & $66.02 \pm 0.75$ & 30.21 & $6.18 \pm 0.15$ & $5.60 \pm 0.22$ & 777.71 \\
\hline Rhizopus nigricans & $64.02 \pm 0.84$ & 32.33 & $5.78 \pm 0.14$ & $6.14 \pm 0.59$ & 763.11 \\
\hline R. oryzae & $36.20 \pm 0.65$ & 61.73 & $5.80 \pm 0.13$ & $5.25 \pm 0.39$ & 400.01 \\
\hline Trichoderma viride & $50.27 \pm 0.52$ & 46.86 & $7.21 \pm 0.16$ & $3.58 \pm 0.30$ & 542.41 \\
\hline Control & $94.61 \pm 0.46$ & & $8.89 \pm 0.19$ & $6.65 \pm 0.17$ & \\
\hline SEm & 1.17 & & 0.10 & 0.13 & \\
\hline $\operatorname{LSD}(.05)$ & .011 & & .005 & .000 & \\
\hline
\end{tabular}

Mean \pm SEm, $\mathrm{n}=3$

All the fungi produced toxic metabolites and especially Aspergillus niger and Rhizopus oryzae produced large quantities as indicated by the reduction of percentage germination of seeds. The result corroborate with the findings of Vidhyasekharan et. al. (1970). High concentrations of filtrate (100 and $75 \%$ ) were found to have more inhibitory effect on seed germination than lower concentrations (50 and 25\%). Reduction in seed germination was found to be directly proportional to the concentration of culture filtrate. These effects on seed germination may be due to inhibitory factor present in the fungal culture filtrate (Tiwari 1993). Reduction in seed germination percentage when seeds were soaked in the filtrates of Aspergillus niger, A. flavus, Alternaria alternata, Fusarium oxysporum and Penicillium sp. has been reported earlier (Ibraheem et al. 1987). The role of toxic metabolites of Aspergillus sp., Fusarium sp. and Penicillium sp. in reducing germination and seedling development has been reported by pervious workers
(Umecharuba \& Nwachukwu 1997, Nema 1992, Vazquez et al. 1993, Madhosing 1995).

It is evident that the seeds of Aijung rice variety carry a heavy load of seed borne fungi which are responsible for loss in seed germination and seedling vigour. It may be stated that it needs a long-term detailed study involving various aspects of seed mycota of Aijung rice in order to exploit the potentiality for improvement of quality of seed in Assam.

\section{References}

Baki AA, Anderson JD. 1972 - Physiological and biological deterioration of seeds. In: Seed Biology, Vol. II. Academic Press, New York.

Bateman GL, Kwasna H. 1999 - Effects of number of winter wheat crops grown successively on fungal communities on wheat roots. Applied Soil Ecology 13, 271-282.

Dharamvir. 1973 - Studies on reducing post harvest fungal spoilage of seeds. 
Pesticides 7, 26.

Ellis MB. 1971 - Dematiaceous Hyphomycetes. Commonwealth Mycological Institute, London. 608 pp.

Gupta VK, Chouhan JS. 1970 - Seed borne fungi and seed health testing in relation to seedling disease of groundnut. Indian Phytopathology 23, 622-625.

Ibiam OFA, Umechuruba CI, Arnize AE. 2006 - Seed borne fungi associated with seeds of rice (Oryza sativa L.) in storage and from the field in Ohaozara and Onicha local Government areas of Ebonyi State. World Journal of Biotechnology 7, 1062-72.

Ibraheem SA, Okesha, AM, Mhathem, KT. 1987 - Interrelationship between protein and oil content of soyabean seed with some associated fungi. Journal of Agricultural Water Resources Research and Plant Production 6, 53-66.

Imolehin ED. 1987 - The rice seed multiplication centres in relation to seed borne pathogens of rice. A case study of Ondo State Rice Multiplication Centres. Nigerian Journal of plant Protection 11, 37-42.

ISTA 1976- International Rules for Seed Testing. Seed Science and Technology 4, 51-177.

Jaffe AZ. 1968 - Mycota of surface sterilized ground nut kernels. Plant Disease Reporter 52, 608-611.

Jayaweera KP, Wijesundera RLC, Medis SA. 1988 - Seed borne fungi of Oryza sativa. Indian Phytopathology 41, 355358.

Kanapathipillai VS, Hashim ZB. 1982 - Seed borne fungi of Brassica chinensis L. and Brassica rapa L. and their pathogenic importance. The Malaysian Agricultural Journal 53, 90-95.

Kanujia RS, Singh CS. 1975 - Studies on certain aspects of seed borne fungi $\mathrm{V}$. Fungi of some starchy seeds. Phytopathological Notes 28, 299-301.

Khanzada KA, Rajput MA, Shah GS, Lodhi AM, Mehboob F. 2002 - Effect of seed dressing fungicides for the control of seed borne mycota of wheat. Asian Journal of Plant Science 1, 441-444.
Khare MN. 1996 - Methods to test seeds for associated fungi. Indian Phytopathology 49, 319-328.

Madhosing C. 1995 - Relative wilt-inducing capacity of the culture filtrates of isolates of Fusarium oxysporum f.sp. radicis-lycopersici, the tomato crown and root-rot pathogen. Journal of Phytopathology 4, 193-198.

Muskett AE 1948 - Method for the examination of seeds for the presence of seed borne fungi. Transactions of the British Mycological Society 30, 74-83.

Neergard P. 1977 - Seed pathology. Vol I. Macmillan, London. 839 pp.

Nema AG. 1992 - Studies on pectinolytic and cellulolytic enzymes produced by Fusarium udum causing wilt of pigeonpea. Indian Forest Journal 15, 353-355.

Paul YS. 1989 - Seed borne mycota of soybean and its control in Himachal Pradesh. Indian Journal of Mycology and Plant Pathology 119, 235-257.

Popoola TOS, Akueshi CO. 1986 - Seed borne fungi and bacteria of soyabean (Glycine $\max$ (L.) Merr) in Nigeria. Seed Research 14, 170-176.

Prasad R, Chaudhary KCB. 1978 - Seed treatment to control root-rot of lentil. Farm Science Journal 2, 112-115.

Ram J, Choudhary SL, Jain KL, Dhinu VK, Ram J. 1997- Effect of culture filtrates of seed mycota of lentil on seed germination and seedling survival. Indian Journal of Mycology and Plant Pathology 27, 342-343.

Singh SD, Swami SD. 2004 - Pathogenic potential of seed mycota of pearl millet [Pennisetum glaucum (L.) R.Br.]. Journal of Mycology and Plant Pathology 34, 122-124.

Subramanyam P. 1991 - Control of seedling disease of groundnut. Nigerian Tropical Pest Management 37, 118-119.

Suhag LS, Suryanarayan D. 1975 - Some aspects of seed health testing with respect to seed borne fungi of pulse crops grown in Haryana. Indian Journal of Mycology and Plant Pathology 6, 32-36.

Suryanarayana D. 1978 - Seed Pathology. 
Vikas Publishing House, New Delhi. $111 \mathrm{pp}$.

Tiwari V. 1993 - Toxic effect of food borne fungi on seed health. Indian Journal of Mycology and Plant Pathology 23.

Umecharuba GI, Nwachukwa, EO. 1997- The effect of filtrates of seed-borne fungi of African yam bean on seed germination and seedling development. Global Journal of Pure and Applied Sciences 3, 165-176.

Utobo EB, Ogbodo EN, Nwogbaga AC. $2011-$ Seed borne mycota associated with rice and their influence on growth of Abakaliki, Southeast agro-ecology, Nigeria. Libiyan Agriculture Research Center Journal International 2, 79-84.

Vazquez C, Reyes F, Martinez MJ. 1993 Comparative studies of pectic activities from different formae specials
Fusarium oxysporum. Applied Microbiology 16, 210-213.

Vidhyasekharan P, Subramanian CL, Govindaswamy CV. 1970 - Production of toxins by seed-borne fungi and its role in paddy seed spoilage. Indian Phytopathology 23, 518-525.

Vijayan AK, Rehill PS. 1990 - Effect of culture filtrates of some seed borne fungi of Dalbergia sissoo Roxb. on seed germination and seedling growth. Indian Forester 116, 559-563.

Vishnuvat K, Shukla P. 1979 - Fungi associated with lentil seeds. Indian Phytopathology 32, 279-280.

Zope AV, Thrimurty VS. 2004 - Effect of botanical pesticide on seed, rhizosphere microflora and seedling vigour in rice. Journal of Mycology and Plant Pathology 34, 576-578. 